\title{
Thirteen Under the Tree
}

Sour bitter crab apple day

Taste the pain dripping between the leaves

I don't understand what mum did to me

Broken brush; three years missing

There's no "I got it wrong"

No hugs, no kisses, no forgiveness

Just rage dragging me by the hair

I'm a male and I must pay

And she's always right

The astral plane confirms her actions

Driving me out of the house

Company with the rain

I know she's too far gone

I cup my hands

Plead my innocence

The door slams in my face

Anger of a child, "You psycho bitch"

Blinds drawn down

Not anyone's problem

So short I'm freezing

"Thank you"

"I hate your guts"

I'll pray to anyone who'll listen

No help inside or out

Thirteen years old in the dark

Rubbing out my tears

One day I think

'I'll have the power'

'Hope I don't treat you as you're treating me'

Sour bitter crab apples I eat

Underneath the tree. 